\title{
Synthesis, structural characterization, modal membrane interaction and anti-tumor cell line studies of nitrophenyl ferrocenes
}

Ataf Ali Altaf ${ }^{1,2,3}$, Bhajan Lal ${ }^{4,5}$, Amin Badshah*,3, Muhammad Usman ${ }^{6}$, Pabitra B. Chatterjee ${ }^{2}$, Fazlul Huq $^{5}$, Shafiq Ullah ${ }^{3}$, Debbie C. Crans ${ }^{2, *}$

${ }^{1}$ Department of Chemistry, University of Gujrat, Hafiz Hayat Campus, Gujrat, Pakistan 50700

${ }^{2}$ Department of Chemistry, Colorado State University Fort Collins, CO. USA 80523

${ }^{3}$ Department of Chemistry, Quaid-i-Azam University Islamabad, Pakistan.45321

${ }^{4}$ Faculty of Engineering, Sukkur Institute of Business Administration, Sukkur Pakistan

${ }^{5}$ School of Biomedical Sciences, Cumberland Campus, C42, University of Sydney, Australia

${ }^{6}$ Department of Chemistry, Government College University Faisalabad, Pakistan. 38000

*Correspondence e-mails

Amin Badshah; aminbadshah@yahoo.com, Debbie C.Crans; crans@lamar.colostate.edu

\begin{abstract}
A series of nitrophenyl ferrocens (A1 - A5) were synthesized and fully characterized in solid state (using CHN analysis, FTIR and single crystal XRD) as well as in solution phase $\left({ }^{1} \mathrm{H} \&{ }^{13} \mathrm{C}\right.$ NMR and UV-visible spectroscopy). Micelle interface interactions of these compounds were explored and found to have ability across a micelle membrane interface. Interestingly, these compounds exhibited $\pi$-electronic push pull systems and oxidation of ferrocene to ferrocenium on crossing the negative interface of the micelle membrane. Selective compounds were screened for antitumor activity against parental and drug resistant human ovarian tumor models i.e. A2780 and A2780 cisR,$A 2780^{\text {ZD0473R }}$. Screened compounds were found to overcome resistance factor compared to cisplatin.
\end{abstract}

Keywords: Ferrocene; Modal membrane; Antitumor cell line; Human ovarian tumor 


\section{Introduction}

Ferrocenyl derivatives with low oxidation potentials are attracting attention of many researchers due to their ability to catalyze the production of reactive oxygenated species (ROS), under physiological conditions that generates cytotoxic effects $[1,2]$. Many ferrocene derivatives have shown cytotoxicity against lung tumors, breast cancer, the anti-proliferative effect in vitro, DNA detection and anti-malarial activity $[3,4]$. One of the most interesting property of ferrocene is its lipophilic nature that can also be induced to its derivatives, which attracted many bio-organometallic chemists. [5].

In the struggle for searching effective anticancer drugs, tremendous attention has been paid to ferrocene and its derivatives in view of their potential applications in medical field [6,7]. It has been established that ferrocenes have appreciable anti-neoplastic activity [8, 9]. Many commercial drugs are going to substitute by their ferrocene analogs. Studies show that the insertion of ferrocene in existing drugs enhances their activities many fold. Insertion of ferrocene in peptide structures increased their anticancer activity [10-13], ferrocenyl-cisplatin also been reported [14], chloroquine is going to replaced by ferrochloroquine [15] (ferrocene analog) and a one of the best examples is the discovery of ferrociefen [5], a ferrocene analogue of tamoxifen that is in clinical trials for breast cancer treatment, and give very impressive results [16].

Ovarian carcinoma is the sixth most common malignancy in women and is the leading cause of death from gynecologic malignancy in the western world [17]. It is believed that the vast majority $(85-90 \%)$ of ovarian cancers are epithelial in origin [18]. Although the exact causes of ovarian cancer remain unknown, a number of genetic and environmental risk factors have been identified. Among the genetic factor, Mutations in the BRCA1 and BRCA2 tumor suppressor genes can cause ovarian cancer. These genes normally help to prevent cancer by producing proteins that carry out functions such as: recognition or repair of certain forms of DNA damage and thus the damaged DNA cause ovarian cancer $[19,20]$. Cisplatin is vastly employed to treat ovarian cancer, but the A2780 ovarian cancer cells have gotten the resistance against cisplatin. The mechanisms of resistance to cisplatin are believed to be: (I) reduced drug accumulation in cells, (II) enhanced repair of DNA damage [21-23]. Keeping these considerations in mind, we focus to design such molecules those interact differently with DNA in reference to cisplatin which infect slow down DNA repair. Shah et al. (2010) reported the electrostatic DNA binding (different from cisplatin that is covalent binder) of 4-nitrophenyl ferrocene (A1) [24]. So in connection we synthesized a series of similar compounds. 
Considering its hydrophobic nature the ferrocene has potential to overcome some of the transport issues and thus reduce toxicity; we checked the interactions with interfaces using micelles - and found confirmation that the concept worked. However, to really solidify this concept - we tested them in cell culture, specifically A2780 and A2780 ${ }^{\text {cisR }}$, A2780 ${ }^{\text {ZD0473R }}$ human ovarian cell lines.

\section{Results and Discussion}

\subsection{Synthesis and Characterization:}

Synthesis: A1 - A5 were prepared by reacting ferrocene with diazonium salt of mono and di-substituted anilines as shown in scheme 1. The reactions were carried out in the ether-water (1:1) mixture using $\mathrm{CTAB}$ as a phase transfer catalyst in analogy with previous preparations of many different ferrocene derivatives [25]. The presence of the phase transfer catalyst increase the yields from about $15 \%$ to $>$ 70\% for A1 - A5 in agreement with literature reports on other substituted ferrocene derivatives [26, 27]. Compounds A1 - A5 were characterized by using multinuclear ${ }^{1} \mathrm{H}$ and ${ }^{13} \mathrm{C}$ NMR and FT-IR spectroscopy. The formation of A1 - A5 was confirmed by spectral data ( ${ }^{1} \mathrm{H} \&{ }^{13} \mathrm{C}$ NMR and IR) which revealed the characteristic peaks of ferrocene in their usual region [28]. The CHN elemental analysis data showed close agreement with theoretical value as detailed in the experimental section.

$<$ Scheme 1>

Solution Characterization: The A1-A5 were soluble in both aprotic solvents such as hexane, heptane, THF, DMSO, DMF, acetonitrile, acetone, dichloromethane and protic solvents such as methanol and ethanol. The solubility of the A1-A5 in isooctane is less than $0.6 \mathrm{mM}$ and observed even lower than that for other solvents. An attempt was made to dissolve A1 - A5 in water with very low concentrations with extensive sonication and found to be insoluble.

$<$ Figure $1>$

The UV-Visible spectrum of ferrocene $(\mathrm{Fc})$ showed two absorption bands which is attributed to three

spin-allowed ligand field transitions i.e.: ${ }^{1} \mathrm{~A}_{1 \mathrm{~g}} \rightarrow \mathrm{a}^{1} \mathrm{E}_{1 \mathrm{~g}},{ }^{1} \mathrm{~A}_{1 \mathrm{~g}} \rightarrow{ }^{1} \mathrm{E}_{2 \mathrm{~g}}$, and ${ }^{1} \mathrm{~A}_{1 \mathrm{~g}} \rightarrow \mathrm{b}{ }^{1} \mathrm{E}_{1 \mathrm{~g}}$. The first two transitions are unresolved and give rise a band at 442nm in the absorption spectrum of Fc in THF at room-temperature. The third transition is responsible for the absorption band at $325 \mathrm{~nm}$. Both bands are weak owing to the Laporte-forbidden $d-d$ character of ligand field transitions [29-31]. Higher-energy features in the electronic absorption spectrum of Fc arise from intramolecular charge transfer transitions. In iso-pentane, the intense band at $200 \mathrm{~nm}$ has been assigned as ligand-to-metal charge transfer (LMCT) 
in character [32]. Shoulders observed at $265 \mathrm{~nm}$ and $240 \mathrm{~nm}$ are attributed to LMCT and metal-to-ligand charge transfer (MLCT) transitions respectively [31]. The UV-Visible spectrum changed dramatically upon substitution of the cyclopentadienyl ring with conjugated and acceptor groups, as was observed for nitro-phenyl groups. Molar absorptivity values showed that all these compounds exhibit a metal-toligand-charge-transfer (MLCT) band about $500 \mathrm{~nm}$ and a band below $300 \mathrm{~nm}$ which is mainly due to ligand. In these complexes, this MLCT signal is at higher wavelengths compared to $\mathrm{Fc}$ and overlapped the $\mathrm{d}-\mathrm{d}$ transitions of ferrocene moiety.

This wavelength $\left(\lambda_{\max }\right)$ is solvent dependent whereas the intensity of the signal changed by mixing of MLCT band. For example, studies for A1 revealed that the MLCT band in isooctane is at $480 \mathrm{~nm}$ with lower signal intensity. This has been observed for other ferrocene derivatives [31]. The nonpolar solvents supported a high energy, low wavelength $\left(\lambda_{\max }\right)$ absorption whereas, polar solvent found to have low energy, high wavelength $\left(\lambda_{\max }\right)$ as shown in figure 1 and table 1 . As explained in the energy level diagram (figure 1) electron withdrawing substituent reduce the gap between HOMO and LUMO for the MLCT band which increase the value of $\lambda_{\max }$ drastically in the A1 - A5. The energy gap also affected by the change of solvent, the polar solvent (like acetonitrile, EtOH, and THF) had the ability to donate electrons in the LUMO of the compound and lowered the energy of orbital's and hence band gap between these energy levels decreased as a result the $\lambda_{\max }$ shifted towards higher value. Conversely the electron loving polar solvents (like EtOH have ability of forming H-bonding with $\pi$-electronic cloud) did not affect the LUMO energy level, but enhance the energy of HOMO and hence decreased the gap between these two energy levels yielding higher value of $\lambda_{\max }$ with lower energy in comparison to the non-polar solvent. Since the MLCT is at a lower $\lambda_{\max }$ suggesting less conjugation between the ferrocene and phenyl ring in these solvents.

These studies demonstrate that this class of compounds not only had diversity with regard to conjugation between $\mathrm{Cp}$ ring and phenyl group, but also with regard to conformation as well. Examples of this type of conformational rotation have been observed in the solid state for $\mathbf{A 1}[33,34]$.

$$
<\text { Table } 1>
$$

A1 - A5 were examined using ${ }^{1} \mathrm{H}$ NMR spectroscopy. Substituted ferrocene moiety gave rise three signals in the range $4-5 \mathrm{ppm}$. The intense signal, with an integration of five protons, was assigned to the un-substituted $\mathrm{Cp}$ ring, and the two other signals were assigned to the protons of the substituted $\mathrm{Cp}$ ring. In ${ }^{13} \mathrm{C}$ NMR, Substituted ferrocene substituted compounds gave rise four signals in the range $60-$ $85 \mathrm{ppm}$. The highest intensity band was assigned to the un-substituted $\mathrm{Cp}$ ring, band with less intensity 
was assigned to the tertiary carbon on which substitution took place and the two other signals were allocated to the other carbons on the substituted $\mathrm{Cp}$ ring. However, all the aromatic protons and carbons fall in their normal expected regions in their respective spectra.

X-ray Crystal Structure: The molecular structure of A2 was determined by single-crystal X-ray diffraction technique. Data pertaining to the data collection and structure refinement showed that A2 was crystallized in the monoclinic crystal system with P21/c space group. Multi-scan absorption correction method was used. The other crystal parameters, calculated at $296 \mathrm{~K}$ using Mo $\mathrm{K}_{\alpha}(\lambda=$ 0.71073 ) radiations, were empirical formula $\mathrm{C}_{16} \mathrm{H}_{12} \mathrm{NO}_{2} \mathrm{ClFe}$, unit cell dimensions $\mathrm{a}=11.7790(6) \AA, \mathrm{b}=$ 9.6666(5) $\AA, c=25.3185(13) \AA, \beta=90.096(4)^{\circ}, \mathrm{Mr}=341.57$, Volume $=2715.0(4) \AA^{3}, \mathrm{Z}=8$, Density $=$ $1.671 \mathrm{~g} / \mathrm{cm}^{3}$, Crystal size $=0.52 \times 0.44 \times 0.26 \mathrm{~mm}^{3}$, Index ranges $(\mathrm{h}, \mathrm{k}, \mathrm{l})_{\max }=(14,36,18),(\mathrm{h}, \mathrm{k}, 1)_{\min }=$ $(-14,-36,-17)$, Total reflections $=10440, \mathrm{Mu}=1.309 \mathrm{~mm}^{-1}, \theta_{\max }=33.27^{\circ}, \mathrm{R}=0.0325$ and $\mathrm{wR} 2=$ 0.1289 .

Table 2 provides a selection of the most important inter atomic distances, bond angles and torsion angles. The ORTEP representation of molecular structure with a numbering scheme of $\mathbf{A 2}$ is given in figure $2 \mathrm{X}$. The intra-molecular hydrogen bonding and intermolecular interactions present in it, are summarized in table 3 and drawn in figures 2 ( $\mathrm{Y}$ and $\mathrm{Z}$ ).

\section{$<$ Table 2>}

The single crystal X-ray results revealed that in $\mathbf{A} 2$ the planes of the cyclopentadienyl ring A (C6-C10) and phenyl ring B $(\mathrm{C} 11-\mathrm{C} 16)$ crossed each other with the dihedral angle of $24.88^{\circ}$, however the nitro group was in plane with phenyl ring B (dihedral angle is $2.95^{\circ}$ ). The Fe-atom was at a distance of 1.651 $\AA$ from the centroid of ring A. Widespread conjugation was accountable for planarity along with intramolecular H-bonding as shown in figure 2(Y). The packing diagram of $\mathbf{A 2}$ (figure 2(Z)) showed the molecule was stabilized by zig zag chain formation along the crystallographic b-axis, structure mediated by NO --- HC intermolecular hydrogen bonding. Such kind of non-bonding secondary interactions are important for the biological activities of a compounds [13].

\section{$<$ Table 3>}

$<$ Figure $2>$

The conformation and rotation of the phenyl group out of the plane of the ferrocene is about $22.4^{\circ}$ in $\mathbf{A 4}$, 24.9 $9^{\circ}$ in $\mathbf{A 2}$ and $17.46^{\circ}$ in A5. 4-nitrophenylferrocene A1 had previously been characterized using X-ray crystallography and three different structures had been reported (table 4) [33-35]. These structures 
differed in the torsion angle responsible for the conjugation between the ferrocene and the phenyl group. In $\mathbf{A 1}$ there was no $o$-substituent and the observed effects were due to the more favorable conformation. The fact that three different structures would be observed document the flat energy surface of these types of structures, and that conjugation between the ferrocene and the phenyl group was not important to the stability of the compound. In the case of structure A4 and A2 the methoxy and chloro groups, respectively, provided some steric hindrance and disturbed the planarity of the ferrocene cyclopentadienyl group and phenyl ring. The conjugation between the phenyl and the ferrocene was also reflected in the $\mathrm{C}-\mathrm{C}$ bond length between the ferrocene and phenyl ring.

$<$ Table $4>$

Since this bond length was shorter for the $p$-nitro substituted derivatives provides the evidence of push pull delocalization of the $\pi$ electrons. Whereas in non-conjugated systems and the $m$-nitro substituted derivative A5; the concerned bond was elongated in comparison to electron withdrawing (A1, $\mathbf{A 2}$ and A4) and donating ( $p$-ferrocenylaniline) conjugated systems. Therefore the observation of near planar phenyl group and ferrocene group was not anticipated. The conformer observed was particularly surprising, because one could anticipate some electrostatic interaction between the oxygen atom and the iron atom might exist. Since the distances between the ortho carbon atom of structure A4 and that of the corresponding phenyl derivatives were very similar, there was no structural support for such attraction, as it was expected that the torsion angle should be larger in the A4 than in $\mathbf{A 2}$ due to the larger size of the methoxy group [36], but the observed values were opposite to the expectation. One could anticipate that it might be due to intra-molecular hydrogen bonding (shown in figure $2(\mathrm{Y})$ ), as oxygen was more electronegative than chlorine.

\subsection{Modal Micelle Membrane studies}

Modal membrane interfaces of cetyltrimethylammonium bromide (CTAB), tetradecyltrimethylammonium bromide (TTAB) and sodium dodecylsulphate (SDS) were made to check the ability of these potential drug molecules to penetrate across membrane. These potential drug molecules were probed by using sophisticated techniques like UV-visible and ${ }^{1} \mathrm{H}$ NMR spectroscopy. Ferrocene and its derivatives are highly sensitive to the oxidation and showed a remarkable change in the UV-visible spectrum. On oxidation; ferrocene gave entirely different colored ferrocenium ions with positive charge overall on the complexes which had one unpaired electron that gives $d$-d transition in the region of $650-750 \mathrm{~nm}$ with a deep green color whereas ferrocene itself has brown color. 
Initially $\mathrm{CTAB}$ were used as a positive membrane for $\mathbf{A} \mathbf{1}$ and the probing were done at $37{ }^{\circ} \mathrm{C}$ (well above the micelle formation temperature of CTAB) afterward CTAB was replaced with TTAB and probing were done at $25{ }^{\circ} \mathrm{C}$ for TTAB and SDS. All the compounds A1 - A5 were insoluble in water and gave no peak in UV-visible spectrum. These compounds showed uptake in the micelle membranes of CTAB, TTAB and SDS. These gave characteristic MLCT bands in the UV-visible spectrum when probed in CTAB (for A1 only) and TTAB micelle (Figure 3). The change in $\left(\lambda_{\max }\right)$ data is given in the table 4. When these compounds were probed in the SDS negative membrane a new band at about $650-$ $715 \mathrm{~nm}$ was appeared, This new band may be assigned to the oxidation of ferrocene to ferrocenium specie in accordance with literature [37].

$<$ Figure $3>$

It was interesting to see that the oxidation band was observed only for A1 - A4, but not for the A5 (figure 3). It seems that nitro group at para position (in compounds $\mathbf{A 1}$ - A4) support the oxidation by strong delocalization of $\pi$-electronic cloud and facilitate the un-pairing of electrons in ferrocene. That strong delocalization is not possible in A5 (Meta substituted nitro derivative) which is in accordance with classical organic chemistry.

$<$ Table 5>

The probing of these compounds was also done by using ${ }^{1} \mathrm{H}$ NMR spectroscopy in addition to UVvisible spectroscopy. NMR is highly sensitive technique in this regard. It gives lot of information about the small molecule - micelle membrane interaction qualitatively as well as quantitatively. In this regard qualitative information relates to the position of the probe molecule in/outside of the micelle membrane, and its extent to penetrate into the micelle membrane. The relative integration value reveals the number of penetrating molecules per micelle (quantitative information).

$<$ Figure $4>$

The chemical shift values and the quantitative data of compounds are given in the table 5. The quantitative data showed that A5 (having 2.86 molecules per micelle) have the highest lipophilic nature among the tested compounds. It might be due to the presence of nitro group at the meta-position which decreased the dipole moment (qualitatively we can judge A5 should have least dipole moment among these) and make the molecule non-polar. The change of the substitution on the phenyl ring disturbed the planarity between the phenyl and $\mathrm{Cp}$ rings of the molecule and result in the change of polarity and lipophilic behavior. 
On the basis of the change in chemical shift value we are able to comment on the position of the probe molecules (A1 - A5) in the micelle membrane system. Results indicate that there is downfield shifting in proton chemical shift values of probe molecule in micelle membrane when compared with solvents like acetone, cyclohexane, isooctane and chloroform for $\mathbf{A 1}$; and with $\mathrm{CDCl}_{3}$ for all the other compounds. It was noticed that ferrocene protons show less downfield shifting as compared to the aromatic protons, which suggested the orientation of nitrophenyl group towards the interface. On comparing ${ }^{1} \mathrm{H}$ NMR data of $\mathbf{A} \mathbf{1}$ for $\mathrm{CTAB}$ and TTAB micelle, the probe molecule felt more acidic environment in the TTAB micelle membrane which might be due to the smaller size of TTAB micelle in comparison to CTAB micelle. As in the small sized micelle the positive membrane is sited near to the probe molecule. From this comparison we may conclude that these molecules were inside the micelle and not existed on the surface of the micelles as the adduct form via ionic interaction between them. (If such kind of adduct exist, then there must be no change in chemical shift of probe $\mathbf{A} 1$ on shifting from CTAB to TTAB). Thus results (given in table 5 and shown in figure 4) clearly infer that these molecules reside inside and in the polar regions of the micelle membrane.

In SDS micelle membrane systems, none of the probe molecule band was appearing in the NMR spectrum which provide the supporting evidence for the proposed oxidation of the ferrocene into ferrocenium species. As the ferrocenium ion is a paramagnetic specie and cannot be observed with simple NMR instrument. For SDS micelle, one can think about the oxidation of the probe due to the protonation of the ferrocene which generate ferrocenium specie due to the presence of normal $\mathrm{RSO}_{3} \mathrm{H}$ impurity in the SDS surfactant. But it must be the least probable chance because the SDS purified using a reported protocol and the SDS used for all compounds were same, then why it does not protonate A5? As A5 doesn't generate any evidence of oxidation in UV-visible spectrum.

Our research group has already reported that these molecules interacted with DNA electrostatically in the major grooves and disturb DNA conformations [24]. The modal membrane interface studies (above) showed that these molecules had the ability to penetrate into positive and negative membranes. So, they can affect the DNA across the cell membrane in the living cell. On the basis of such studies, we screened two of the synthesized compounds (A1 and A5) against available human ovarian cell tumor models: A2780 (parent), A2780 ${ }^{\text {cisR }}$ (cisplatin-resistant type), A2780 ${ }^{\text {ZD0473R }}$ (ZD0473-resistant type) for their potential antitumor activity. 


\subsection{Cell line Screening}

The cell killing effect of compounds A1, A5 and cisplatin was determined against human ovarian cell lines: A2780 (parent), A2780 ${ }^{\text {cisR }}$ (cisplatin-resistant type), A2780 ${ }^{\text {ZD0473R }}$ (ZD0473-resistant type) by using the 3-(4,5-dimethylthiazol-2-yl)-2,5-diphenyltetrazolium bromide (MTT) reduction assay. Table 6 showed the $\mathrm{IC}_{50}$ values and resistance factors $\left(\mathrm{R}_{\mathrm{f}}\right)$. A1 and $\mathbf{A 5}$ were found to be less active than cisplatin against all three cell lines. However $\mathrm{R}_{\mathrm{f}}$ for $\mathbf{A 1}$ and $\mathbf{A 5}$ was found less than that of cisplatin against the $\mathrm{A} 2780^{\mathrm{cisR}}$ and A2780 ${ }^{\mathrm{ZD} 0473 \mathrm{R}}$. It means that at the level of their activity $\mathbf{A 1}$ and $\mathbf{A 5}$ has been better able to overcome mechanisms of resistance operating in the cell lines [38, 39].

$<$ Table 6>

It may be noted that the nature of interaction of $\mathbf{A 1}$ and $\mathbf{A 5}$ with DNA was different (electrostatic) from that of cisplatin [24]. Where as cisplatin binds with DNA by forming mono functional $\mathrm{Pt}(\mathrm{G})$ and intrastrand bifunctional 1,2-Pt(GG) and 1,2-Pt(AG) adducts [40, 41]. This means that $\mathbf{A 1}$ and $\mathbf{A 5}$ might not cause any significant change in DNA conformation. Significant variation in the $\mathrm{IC}_{50}$ values of $\mathbf{A 1}$ and A5, against parent human ovarian cell line A2780, indicates that this may well be due to the different behavior of these molecules in membrane interaction and DNA binding strength. Whereas against drug resistant cell line no significance change in $\mathrm{IC}_{50}$ values was observed.

\section{Conclusions}

Nitrophenyl ferrocenes (A1 - A5) were synthesized in good yield. These compounds presented very interesting example of rotational conformers around the ferrocene-phenyl bond in solution form as well as in the solid state, which exhibited interesting properties to these compounds. They have ability to penetrate into the bio-mimetic micelle membrane and stay just inside the membrane and it may be concluded that negative membrane of SDS micelle oxidized the ferrocenyl push-pull systems those were supportive to the stabilization of ferrocenium ions by the delocalization of one unpaired electron over the whole molecule due the presence of strong electron withdrawing $\mathrm{NO}_{2}$ group at the para position in A1 - A4 but not in A5. In human ovarian tumor models: A2780 (parent), A2780 ${ }^{\text {cisR }}$ (cisplatin-resistant type), A2780 ${ }^{\text {ZD0473R }}$ (ZD0473-resistant type) cytotoxicity assay for A1 and A5 showed decreased resistance factor $\left(\mathrm{R}_{\mathrm{f}}\right.$-value) compared to cisplatin.

\section{Experimental}

Materials and methods. Ferrocene, 4-nitroaniline, 2-methyl-4-nitroaniline, 2-methoxy-4nitroaniline, 2-chloro-4-nitroaniline and 3-nitroaniline were purchased from Acros Organics (Geel, Belgium), sodium nitrite, cetyltrimethylammonium bromide (CTAB), tetradecyltrimethylammonium 
bromide (TTAB), sodium dodecylsulphate (SDS), hydrochloric acid, diethyl ether and other solvents were purchased from Aldrich. All the chemicals purchased were of analytical reagent grade and used as such. Double distilled and deionized water (17.5 $\mathrm{M} \Omega \mathrm{cm}$ Barnstead E-pure) was used. $\mathrm{D}_{2} \mathrm{O}$ (99.9\%) was acquired from Cambridge Isotope Laboratories Andover, MA. USA. Infrared spectra were recorded on Thermo Scientific Nicolet-6700 FTIR spectrometer and NMR spectra were obtained at Varian MR $400 \mathrm{MHz}$ NMR spectrometer using routine parameters. UV-visible spectrometric measurements were recorded on Perkins Erlenmeyer lambda-25 UV-visible spectrometer. Elemental analysis was carried out from Columbia Analytical Services, Tucson, AZ. USA.

Synthesis of 4-nitrophenylferrocene (A1); Compound(A1) was synthesized using the literature reported method with some modifications [25]. 4-nitroaniline (14 g, $100 \mathrm{mmol}), 30 \mathrm{ml}$ of water and 30 $\mathrm{ml}$ of concentrated hydrochloric acid were mixed together and cooled to $0-5{ }^{\circ} \mathrm{C}$ using salt water-ice bath. A solution of sodium nitrite $(7 \mathrm{~g}, 100 \mathrm{mmol})$ in $50 \mathrm{ml}$ of water was added drop wise under stirring at $0-5{ }^{\circ} \mathrm{C}$. After complete addition, the solution was stirred additional 30 min and kept below $5{ }^{\circ} \mathrm{C}$ during this period. Ferrocene $(9.5 \mathrm{~g}, 50 \mathrm{mmol})$, and $0.5 \mathrm{~g}$ (CTAB) were added to $150 \mathrm{ml}$ ethyl ether and cooled to $0-5{ }^{\circ} \mathrm{C}$. The diazonium salt solution was added drop wise to CTAB containing ferrocene solution with stirring, keeping temperature below $5{ }^{\circ} \mathrm{C}$. After the complete addition, the reaction mixture was stirred overnight at room temperature. The mixture was concentrated by rotary evaporation and the residue was washed with excess water, then the crude solid was steam distilled to recover un-reacted ferrocene. The residual crude product was recrystallized from heptane to give 4-nitrophenylferrocene as violet plates (14.2 $\mathrm{g}, 73.6 \%),{ }^{1} \mathrm{H}$ NMR $\left(\mathrm{CDCl}_{3}, \mathrm{ppm}\right) 8.14(\mathrm{~d}, j=8.8 \mathrm{~Hz}, 2 \mathrm{H}), 7.56(\mathrm{~d}, j=8.8 \mathrm{~Hz}, 2 \mathrm{H})$, $4.74(\mathrm{t}, j=1.8 \mathrm{~Hz}, 2 \mathrm{H}), 4.48(\mathrm{t}, j=1.8 \mathrm{~Hz}, 2 \mathrm{H}), 4.06(\mathrm{~s}, 5 \mathrm{H}) .{ }^{13} \mathrm{C} \mathrm{NMR}\left(\mathrm{CDCl}_{3}, \mathrm{ppm}\right) 148.2,145.5$, 125.9, 123.8, 81.7, 70.5, 70.0, 67.2. FTIR (KBr, v cm $\left.{ }^{-1}\right)$ 2990, 1596, 1506, 1340, 1286, 1105, 1080, 847, 756, 696, 505, 472. Anal. Calc. for $\mathrm{C}_{16} \mathrm{H}_{13} \mathrm{FeNO}_{2} \mathrm{C}, 62.57 ; \mathrm{H}, 4.27 ; \mathrm{N}, 4.56$ found $\mathrm{C}, 62.54 ; \mathrm{H}$, $4.28 ; \mathrm{N}, 4.55 \%$.

2-Chloro-4-nitrophenylferrocene (A2); the compound (A2) was synthesized by analogous method as described for A1. Mole ratio used was 2-chloro-4-nitroaniline (1 M equiv), sodium nitrite (1 M equiv) and Ferrocene ( $0.50 \mathrm{M}$ equiv). 2-chloro-4-nitrophenylferrocene was crystallized as violet crystals from heptane. Yield (63.5\%), ${ }^{1} \mathrm{H}$ NMR $\left(\mathrm{CDCl}_{3}, \mathrm{ppm}\right) 8.21(\mathrm{~s}, 1 \mathrm{H}), 8.01(\mathrm{~d}, j=8.0 \mathrm{~Hz}, 1 \mathrm{H}), 7.73(\mathrm{~d}, \mathrm{j}=8.0$

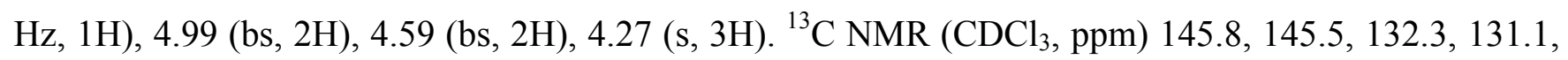
125.8, 121.2, 81.3, 70.3, 70.1. FTIR (KBr, v cm $\left.\mathrm{cm}^{-1}\right) 3104,3074,2923,1592,1585,1514,1336,1105$, 
885, 864, 821, 759, 744, 715, 511, 469. Anal Calc. For $\mathrm{C}_{16} \mathrm{H}_{12} \mathrm{FeNClO}_{2} \mathrm{C}, 56.26 ; \mathrm{H}, 4.54 ; \mathrm{N}, 4.10$ found C, 56.10; H, 4.69; N, $4.02 \%$.

2-methyl-4-nitrophenylferrocene (A3); the compound (A3) was synthesized by analogous method as described for A1. But different mole ratio used was 2-methyl-4-nitroaniline (1 M equiv), sodium nitrite (1 M equiv) and Ferrocene ( $0.75 \mathrm{M}$ equiv). 2-methyl-4-nitrophenylferrocene was crystallized as violet plates from ethanol. Yield ( 73.2\%), ${ }^{1} \mathrm{H}$ NMR $\left(\mathrm{CDCl}_{3}, \mathrm{ppm}\right) 8.00-7.95(\mathrm{~m}, 2 \mathrm{H}), 7.62(\mathrm{~s}, 1 \mathrm{H}), 4.69(\mathrm{t}, j$ $=1.8 \mathrm{~Hz}, 2 \mathrm{H}), 4.51(\mathrm{t}, j=1.8 \mathrm{~Hz}, 2 \mathrm{H}), 4.23(\mathrm{~s}, 5 \mathrm{H}), 2.52(\mathrm{~s}, 3 \mathrm{H}) .{ }^{13} \mathrm{C} \mathrm{NMR}\left(\mathrm{CDCl}_{3}, \mathrm{ppm}\right) 146.3,136.6$, 130.7, 125.4, 120.5, 80.3, 70.8, 70.6, 69.8, 21.6. FTIR (KBr, v cm $\left.{ }^{-1}\right) 3091,2964,2927,1606,1581$, 1510, 1346, 1132, 1105, 1070, 1002, 876, 829, 802, 750, 717, 557, 472. Anal. Calc. for $\mathrm{C}_{17} \mathrm{H}_{15} \mathrm{FeNO}_{2} \mathrm{C}$, 63.58; H, 4.71; N, 4.36 found C, 63.57; H, 4.69; N,4.41\%.

2-methoxy-4-nitrophenylferrocene (A4); the compound (A4) was synthesized by analogous method as described for A1. Mole ratio used was 2-methoxy-4-nitroaniline (1 M equiv), sodium nitrite (1 M equiv) and Ferrocene ( $0.75 \mathrm{M}$ equiv). 2-methoxy-4-nitrophenylferrocene was crystallized as violet plates from pentane. Yield (68.4\%), ${ }^{1} \mathrm{H}$ NMR $\left(\mathrm{CDCl}_{3}, \mathrm{ppm}\right) 7.79-7.81(\mathrm{~m}, 2 \mathrm{H}), 7.61(\mathrm{~d}, j=8.5 \mathrm{~Hz}, 1 \mathrm{H}), 4.87(\mathrm{t}, j$ $=1.9 \mathrm{~Hz}, 2 \mathrm{H}), 4.42(\mathrm{t}, j=1.9 \mathrm{~Hz}, 2 \mathrm{H}), 4.06(\mathrm{~s}, 5 \mathrm{H}), 4.01(\mathrm{~s}, 3 \mathrm{H}) .{ }^{13} \mathrm{C} \mathrm{NMR}\left(\mathrm{CDCl}_{3}, \mathrm{ppm}\right) 156.5,146.2$, 136.6, 128.6, 116.0, 105.9, 79.6, 69.82, 69.8, 69.5, 55.8. FTIR $\left(\mathrm{KBr}, v \mathrm{~cm}^{-1}\right)$ 3112, 3081, 3016, 2956, 2933, 2916, 1585, 1517, 1334, 1242, 1103, 1078, 1035, 860, 814, 800, 746, 732, 497, 484, 462. Anal. Calc. for $\mathrm{C}_{17} \mathrm{H}_{15} \mathrm{FeNO}_{3} \mathrm{C}, 60.56 ; \mathrm{H}, 4.48 ; \mathrm{N}, 4.15$ found $\mathrm{C}, 60.29 ; \mathrm{H}, 4.51 ; \mathrm{N}, 4.12 \%$.

3-nitrophenylferrocene (A5); the compound (A5) was synthesized by analogous method as described for A1. Mole ratio used was 3-nitroaniline (1 M equiv), sodium nitrite (1 M equiv) and Ferrocene ( 0.75 $\mathrm{M}$ equiv). 3-nitrophenylferrocene was crystallized as dark orange crystals from heptane. Yield (70.2\%), ${ }^{1} \mathrm{H}$ NMR $\left(\mathrm{CDCl}_{3}, \mathrm{ppm}\right) 8.28(\mathrm{~s}, 1 \mathrm{H}), 8.03(\mathrm{~d}, j=9.3 \mathrm{~Hz}, 1 \mathrm{H}), 7.76(\mathrm{~d}, j=7.8 \mathrm{~Hz}, 1 \mathrm{H}), 7.44(\mathrm{t}, j=7.9$

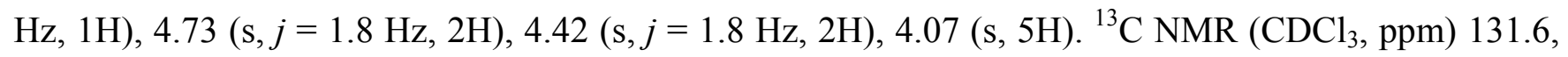
129.2, 120.5, 120.4, 70.6, 69.9, 69.8, 66.8. FTIR $\left(\mathrm{KBr}, v \mathrm{~cm}^{-1}\right)$ 3084, 2931, 1527, 1346, 1105, 742, 723, 675, 478, 462. Anal Calc. For $\mathrm{C}_{16} \mathrm{H}_{13} \mathrm{FeNO}_{2} \mathrm{C}, 62.57 ; \mathrm{H}, 4.27$; N, 4.56 found $\mathrm{C}, 62.49 ; \mathrm{H}, 4.21 ; \mathrm{N}, 4.59$ $\%$.

Micelle Preparation; A $0.1 \mathrm{M}(\mathrm{C}>>\mathrm{cmc})$ stock solution of each CTAB, TTAB and SDS were prepared, dissolving in doubly distilled, deionized water and for NMR studies $\mathrm{D}_{2} \mathrm{O}$ was used, under ambient conditions and CTAB micelles solutions stored at $37{ }^{\circ} \mathrm{C}$. All the compounds A1 - A5 were water insoluble, these solid compounds were sonicated with micelles solutions for 2 hours. 
UV-Visible Spectrometry; Absorption spectra were recorded at a constant temperature of $25{ }^{\circ} \mathrm{C}$ for TTAB and SDS micelles systems, at $37^{\circ} \mathrm{C}$ for CTAB micelles. The electronic spectra of known concentrations of the compounds in different solvents were obtained at room temperature. All the readings were referenced to air by placing empty cell in the path of the reference light beam.

${ }^{1}$ H NMR Spectroscopy of micelles solutions; ${ }^{1} \mathrm{HNMR}$ spectra for CTAB micelles were recorded using a Varian INOVA-300 spectrometer at $37{ }^{\circ} \mathrm{C}$, using standard parameters. All the other ${ }^{1} \mathrm{H}$ NMR spectral measurements were taken at $25{ }^{\circ} \mathrm{C}$ using Varian MR-400 spectrometer. All the chemical shifts were referenced against an external sample of DSS in D2O.

Cytotoxicity Assays; The cytotoxicity of compounds coded as A1 and A5 were screened and compared to cisplatin against human ovarian cell lines: A2780 (parent), A2780 ${ }^{\text {cisR }}$ (cisplatin-resistant type), A2780 ${ }^{\text {ZD0473R }}$ (ZD0473-resistant type) using the 3-(4,5-dimethylthiazol -2-yl)-2,5-diphenyltetrazolium bromide (MTT) reduction assay. Briefly, 4000 to 5000 cells were seeded into the wells of the flatbottomed 96-well culture plate with 10\% FCS/RPMI 1640 culture medium. The plates were incubated for $24 \mathrm{~h}$ in a humidified atmosphere $\left(37^{\circ} \mathrm{C}, 5 \%\right.$ carbon dioxide in the air, $\left.\mathrm{pH} 7.4\right)$ to allow the cells to attach. Four different concentrations of A1 and A5 were added in triplicate wells that were left in the incubator $\left(37^{\circ} \mathrm{C}, 5 \%\right.$ carbon dioxide in the air, $\left.\mathrm{pH} 7.4\right)$ for $72 \mathrm{~h}$. After this period, growth inhibition of cell was determined. $50 \mu \mathrm{L}$ per well of $1 \mathrm{mg} \mathrm{mL}^{-1}$ freshly prepared MTT solution was added to each 96well culture plate. After $4 \mathrm{~h}$, the formazan crystals formed in each well were dissolved in $150 \mu \mathrm{L}$ of DMSO and the absorbance of the resulting solution was read using Microplate Reader (Bio-Rad Modal $3550)$ sets at $550 \mathrm{~nm}[42]$.

\section{Acknowledgement}

We thank the Higher Education Commission (HEC) Pakistan (Project No. PDIPFP/HRD/HEC/2013/30240) and NSF USA “CHE-0628260” for financial support. 


\section{References}

[1] R.L. McCarley,Redox-Based Drug Delivery Systems, Annual Review of Analytical Chemistry, 5 (2012).

[2] S. Hussain, A. Badshah, B. Lal, R.A. Hussain, S. Ali, M.N. Tahir, A.A. Altaf,New supramolecular ferrocene incorporated N, N-disubstituted thioureas: synthesis, characterization, DNA binding, and antioxidant studies, Journal of Coordination Chemistry, 67 (2014) 2148-2159.

[3] M.F. Fouda, M.M. Abd-Elzaher, R.A. Abdelsamaia, A.A. Labib,On the medicinal chemistry of ferrocene, Applied Organometallic Chemistry, 21 (2007) 613-625.

[4] B. Lal, A. Badshah, A.A. Altaf, M.N. Tahir, S. Ullah, F. Huq,Study of New Ferrocene Incorporated N, $\mathrm{N}^{\prime}$-Disubstituted Thioureas as Potential Antitumour Agents, Australian Journal of Chemistry, 66 (2013) 1352-1360.

[5] S. Top, A. Vessieres, G. Leclercq, J. Quivy, J. Tang, J. Vaissermann, M. Huché, G. Jaouen,Synthesis, Biochemical Properties and Molecular Modelling Studies of Organometallic Specific Estrogen Receptor Modulators (SERMs), the Ferrocifens and Hydroxyferrocifens: Evidence for an Antiproliferative Effect of Hydroxyferrocifens on both Hormone - Dependent and Hormone - Independent Breast Cancer Cell Lines, Chemistry-A European Journal, 9 (2003) 52235236.

[6] E.W. Neuse,Macromolecular ferrocene compounds as cancer drug models, Journal of Inorganic and Organometallic Polymers and Materials, 15 (2005) 3-31.

[7] N. Metzler - Nolte,Medizinische Organometallchemie, Nachrichten aus der Chemie, 54 (2006) 966-970.

[8] R. Kovjazin, T. Eldar, M. Patya, A. Vanichkin, H.M. Lander, A. Novogrodsky,Ferrocene-induced lymphocyte activation and anti-tumor activity is mediated by redox-sensitive signaling, The FASEB journal, 17 (2003) 467-469.

[9] R.F. SHAGO, J.C. SWARTS, E. KREFT, C.E.J. VAN RENSBURG,Antineoplastic activity of a series of ferrocene-containing alcohols, Anticancer Research, 27 (2007) 3431-3433.

[10] A. Goel, D. Savage, S.R. Alley, T. Hogan, P.N. Kelly, S.M. Draper, C.M. Fitchett, P. Kenny,The synthesis and structural characterization of $<\mathrm{i}>\mathrm{N}</ \mathrm{i}>-<\mathrm{i}>$ para $</ \mathrm{i}>$-ferrocenyl benzoyl dipeptide esters: The X-ray crystal structure of $<\mathrm{i}>\mathrm{N}</ \mathrm{i}>-\{<\mathrm{i}>$ para $</ \mathrm{i}>$-(ferrocenyl) benzoyl $\}$-1-alanineglycine ethyl ester, Journal of Organometallic Chemistry, 691 (2006) 4686-4693. 
[11] T. Hirao,Control of chirality-organized structures of ferrocene-dipeptide bioconjugates, Journal of Organometallic Chemistry, 694 (2009) 806-811.

[12] A.J. Corry, N. O'Donovan, Á. Mooney, D. O'Sullivan, D.K. Rai, P. Kenny,Synthesis, structural characterization, in vitro anti-proliferative effect and cell cycle analysis of $\mathrm{N}$-(ferrocenyl) benzoyl dipeptide esters, Journal of Organometallic Chemistry, 694 (2009) 880-885.

[13] B. Lal, A. Badshah, A.A. Altaf, M.N. Tahir, S. Ullah, F. Huq,Synthesis, Characterization and Antitumor activity of new Ferrocene incorporated N, N'-disubstituted Thioureas, Dalton Trans., 41 (2012) 14643 - 14650.

[14] E.W. Neuse, M.G. Meirim, N.F. Blom,Metallocene-containing platinum complexes as potential antitumor agents. 1. Dichloro (1, 6-differrocenyl-2, 5-diazahexane) platinum (II) and cisdichlorobis (1-ferrocenylethylamine) platinum (II), Organometallics, 7 (1988) 2562-2565.

[15] B. Pradines, T. Fusai, W. Daries, V. Laloge, C. Rogier, P. Millet, E. Panconi, M. Kombila, D. Parzy,Ferrocene-chloroquine analogues as antimalarial agents: in vitro activity of ferrochloroquine against 103 Gabonese isolates of Plasmodium falciparum, Journal of Antimicrobial Chemotherapy, 48 (2001) 179-184.

[16] R. Frantz, J.O. Durand, G.F. Lanneau,Substituent effects of phosphonate groups electronic repartition of $\pi$-conjugated ferrocene analogues of stilbene, Journal of Organometallic Chemistry, 689 (2004) 1867-1871.

[17] C. Trope, G. Kristensen,current status of chemotherapy in gynaecologic cancer Semin in Oncology, 24 (1997) 5 Suppl. 15.

[18] A.E. Guppy, P.D. Nathan, G.J. Rustin,Epithelial ovarian cancer: a review of current management, Clin Oncol (R Coll Radiol), 17 (2005) 399-411.

[19] A. Bhattacharyya, U.S. Ear, B.H. Koller, R.R. Weichselbaum, D.K. Bishop,The Breast Cancer Susceptibility Gene BRCA1 Is Required for Subnuclear Assembly of Rad51 and Survival following Treatment with the DNA Cross-linking Agent Cisplatin, Journal of Biological Chemistry, 275 (2000) 23899-23903.

[20] M.Z. Muhammad Jamil, Muhammad Asim Farid, Ataf Ali Altaf, Nasir Rasool, Faiz-Ul-Hassan Nasim, Muhammad Ashraf, Muhammad Abid Rashid, Syeda Abida Ejaz, Asma Yaqoob, V.U. Ahmad,Study of Antioxidant, Cytotoxic, and Enzyme Inhibition Activities of Some Symmetrical N3 ,N3'-Bis(disubstituted)isophthalyl-bis(thioureas) and N3 ,N3 ,N3',N3'- 
Tetrakis(disubstituted)isophthalyl-bis(thioureas) and Their $\mathrm{Cu}(\mathrm{II})$ and $\mathrm{Ni}$ (II) Complexes, Journal of the Chemical Society of Pakistan, 36 (2014) 491-497.

[21] M. Ohmichi, J. Hayakawa, K. Tasaka, H. Kurachi, Y. Murata,Mechanisms of platinum drug resistance, Trends in pharmacological sciences, 26 (2005) 113-116.

[22] D. Wang, S.J. Lippard,Cellular processing of platinum anticancer drugs, Nature Reviews Drug Discovery 4(2005) 307-320.

[23] R.M.D.L.C.A. Barabas K.,Cisplatin: a review of toxicities and therapeutic applications, Veterinary and Comparative Oncology, 6 (2008) 1-18.

[24] A. Shah, M. Zaheer, R. Qureshi, Z. Akhter, M.F. Nazar,Voltammetric and spectroscopic investigations of 4-nitrophenylferrocene interacting with DNA, Spectrochim. Acta A, 75 (2010) 1082-1087.

[25] P. Hu, K.-Q. Zhao, H.B. Xu,4-Nitrophenylferrocene, Molecules, 6 (2001) M249.

[26] V. Weinmayr,The Condensation of Dicyclopentadienyliron with Aromatic Diazonium Salts, Journal of the American Chemical Society, 77 (1955) 3012-3014.

[27] K.-Q. Zhao, P. Hu, H.B. Xu,4-Ferrocenylbenzoic Acid.pdf, Molecules, 6 (2001) M246.

[28] B. Lal, A. Badshah, A.A. Altaf, N. Khan, S. Ullah,Miscellaneous applications of ferrocene - based peptides/amides, Appl. Organomet. Chem., 25 (2011) 843-855.

[29] K.N. Jayaprakash, P.C. Ray, I. Matsuoka, M.M. Bhadbhade, V.G. Puranik, P.K. Das, H. Nishihara, A. Sarkar,Ferrocene in Conjugation with a Fischer Carbene: Synthesis, NLO, and Electrochemical Behavior of a Novel Organometallic Push-Pull System\#, Organometallics, 18 (1999) 3851-3858.

[30] A. Thakur, N.N. Adarsh, A. Chakraborty, M. Devi, S. Ghosh,Synthesis of mono and doubly alkynyl substituted ferrocene and its crystal engineering using $-\mathrm{C}-\mathrm{H} \square \square \square \mathrm{O}$ supramolecular synthon, J. Organomet. Chem., 695 (2010) 1059-1064.

[31] Y. Yamaguchi, W. Ding, C.T. Sanderson, M.L. Borden, M.J. Morgan, C. Kutal,Electronic structure, spectroscopy, and photochemistry of group 8 metallocenes, Coord. Chem. Rev., 251 (2007) 515-524.

[32] H.B. Gray, Y.S. Sohn, N. Hendrickson,Electronic structure of metallocenes, J. Am. Chem. Soc., 93 (1971) 3603-3612.

[33] X.-H. Chang,An orthorhombic polymorph of (p-nitrophenyl)ferrocene, Acta Crystallographica Section E Structure Reports Online, 62 (2006) m3544-m3545. 
[34] J.F. Gallagher, G. Ferguson, S.Z. Ahmed, C. Glidewell, A. Lewis,Accurate Redeterminations of 1,1'-Di-benzoylferrocene and (4-Nitrophenyl)-ferrocene, Acta Crystallographica, C53 (1997) $1772-1775$.

[35] R.M.G. Roberts, J. Silver, B.M. Yamin, M.G.B. Drew, U. Eberhardt,Crystal structures of o-, m,and p-nitrophenylferrocenes and their relevance to other sterically crowded phenylferrocenes, Journal of the Chemical Society, Dalton Transactions, (1988) 1549-1556.

[36] M. Smith, J. March, March's advanced organic chemistry: reactions, mechanisms, and structure, Wiley, 2007.

[37] A. Thander, B. Mallik,Charge-transfer spectra of ferrocene in halocarbon solvents under photoexcitation, Proc. Indian Acad. Sci. (Chem. Sci.), 112 (2000) 475 - 485.

[38] H. Tayyem, F. Huq, J.Q. Yu, P. Beale, K. Fisher,Synthesis and Activity of a Trinuclear Platinum Complex: $\quad[\{$ trans-PtCl(NH3) 2$\} 2 \mu$ - $\{$ trans-Pt(3-hydroxypyridine)2(H2N(CH2)6NH2)2\}]Cl4 in Ovarian Cancer Cell Lines, ChemMedChem, 3 (2008) 145-151.

[39] B. Lal, A. Badshah, A.A. Altaf, M.N. Tahir, S. Ullah, F. Huq,Synthesis, Characterization and Antitumor activity of new Ferrocene incorporated N, N'-disubstituted Thioureas, Dalton Transactions, 41 (2012) 14643-14650.

[40] F. Huq, J. Qing Yu, H. Daghriri, P. Beale,Studies on activities, cell uptake and DNA binding of four trans-planaramineplatinum(II) complexes of the form: trans-PtL(NH3)Cl2, where $\mathrm{L}=2$ hydroxypyridine, imidazole, 3-hydroxypyridine and imidazo(1,2- $\alpha)$ pyridine, Journal of Inorganic Biochemistry, 98 (2004) 1261-1270.

[41] A. Abdullah, F. Huq, A. Chowdhury, H. Tayyem, P. Beale, K. Fisher,Studies on the synthesis, characterization, binding with DNA and activities of two cis-planaramineplatinum (II) complexes of the form: cis-PtL (NH3) $\mathrm{Cl} 2$ where $\mathrm{L}=3$-hydroxypyridine and 2, 3-diaminopyridine, BMC chemical biology, 6 (2006) 3.

[42] M.U. Nessa, P. Beale, C. Chan, J.U.N.Q. Yu, F. Huq,Combinations of Resveratrol, Cisplatin and Oxaliplatin Applied to Human Ovarian Cancer Cells, Anticancer Research, 32 (2012) 53-59. 


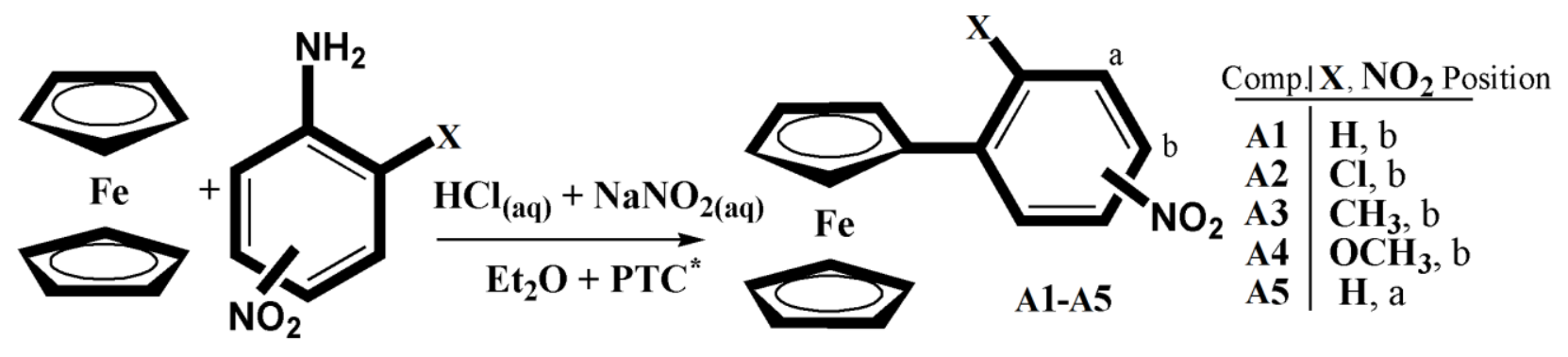

Phe transfer Catalyst i.e., Cetyltrimethylammonium bromide)

Scheme 1: The reaction scheme for the synthesis nitrophenylferrocenes A1 - A5. (PTC=
Phase transfer Catalyst i.e., Cetyltrimethylammonium bromide)

Pcheme 1: The reaction scheme for the synthesis nitrophenylferrocenes $\mathrm{A1}-\mathbf{A 5}$. (PTC=

Pcheme 1: The reaction scheme for the synthesis nitrophenylferrocenes $\mathrm{A1}-\mathbf{A 5}$. (PTC=

Pcheme 1: The reaction scheme for the synthesis nitrophenylferrocenes $\mathrm{A1}$ - A5. (PTC=

Phase transfer Catalyst i.e., Cetyltrimethylammonium bromide)

Pcheme 1: The reaction scheme for the synthesis nitrophenylferrocenes $\mathrm{A1}-\mathbf{A 5}$. (PTC=

Phe trater

$\mathrm{H}_{2}$ Position

列

Phase transfer Catalyst i.e., Cetyltrimethylammonium bromide)

Scheme 1: The reaction scheme for the synthesis nitrophenylferrocenes A1 - A5. (PTC =
Phase transfer Catalyst i.e., Cetyltrimethylammonium bromide)

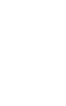

.

.

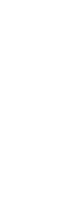

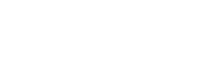



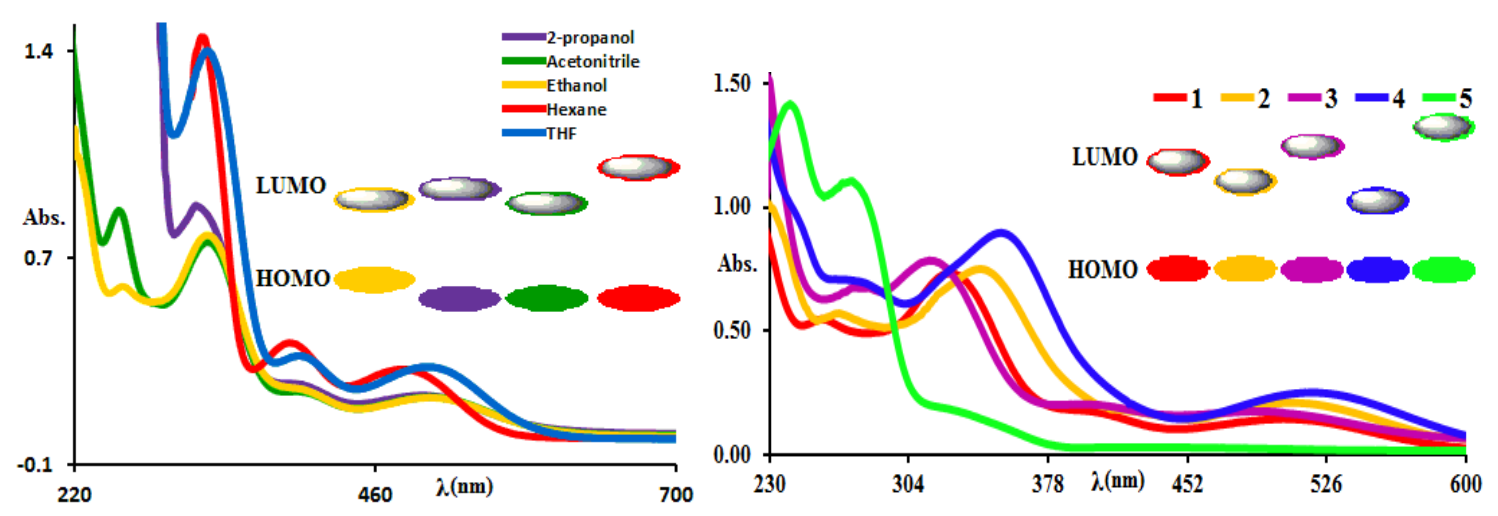

Figure 1: UV-visible spectral response and Qualitative energy levels analysis of compound A1 in different solvents (Left) and compounds A1 - A5 in ethanol (Right). (Colored figure for on line version of the paper) 

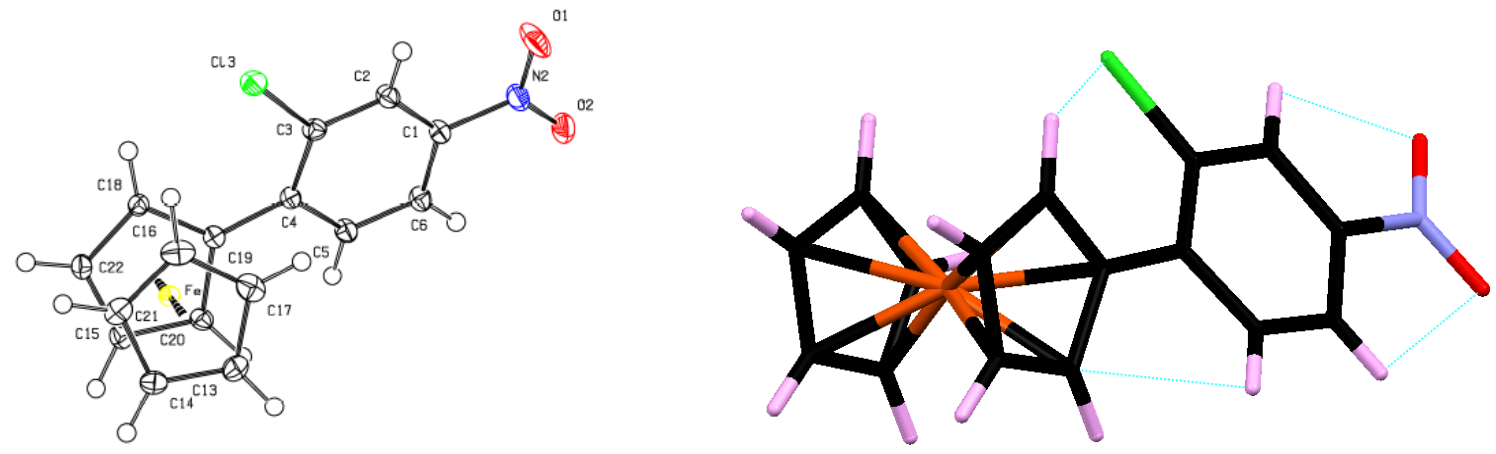

$\mathrm{X}$

$\mathrm{Y}$

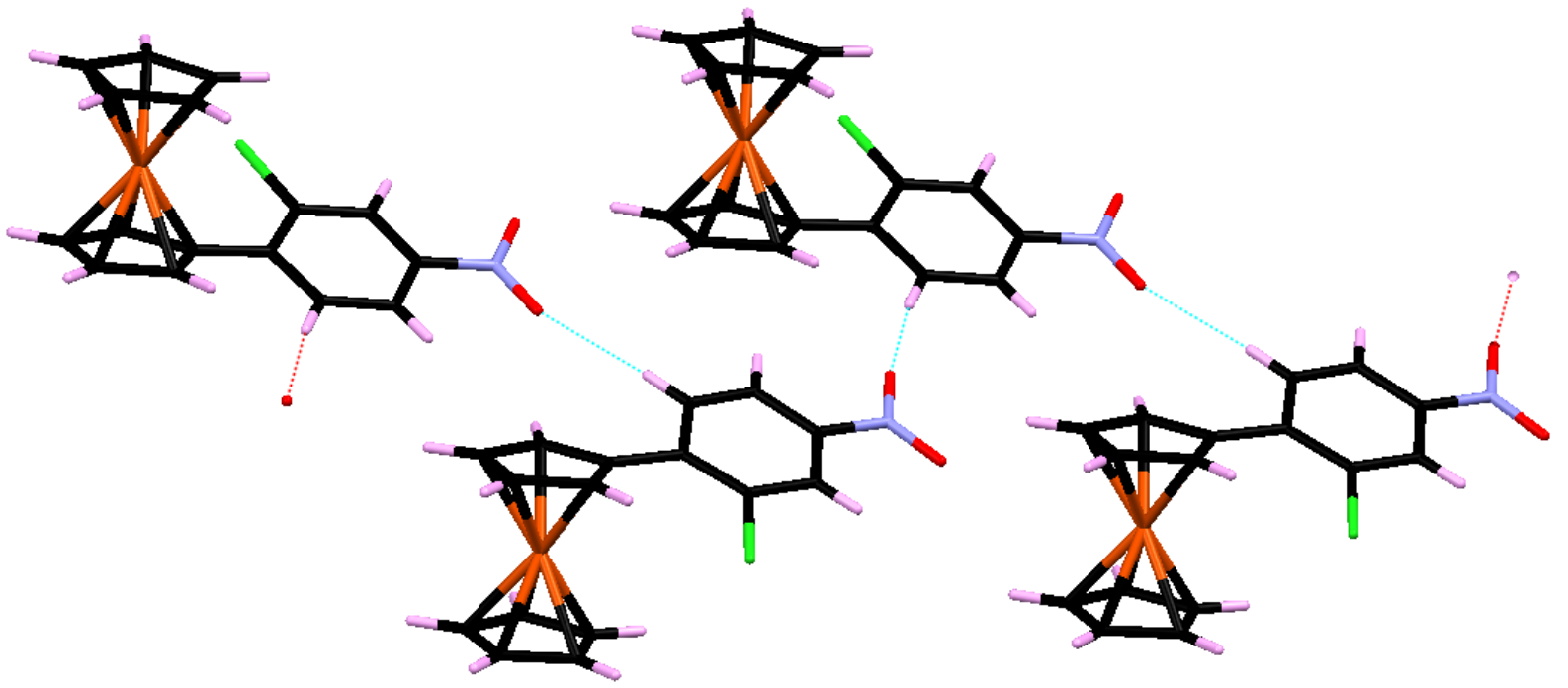

$\mathrm{Z}$

Figure 2: X) ORTEP diagram of A2 with atomic numbering scheme. Y) The intra-molecular Hbonding represented by dotted lines. Z) The supramolecular arrangement of $\mathbf{A 2}$ mediated by intermolecular H-bonding represented by dotted lines. 

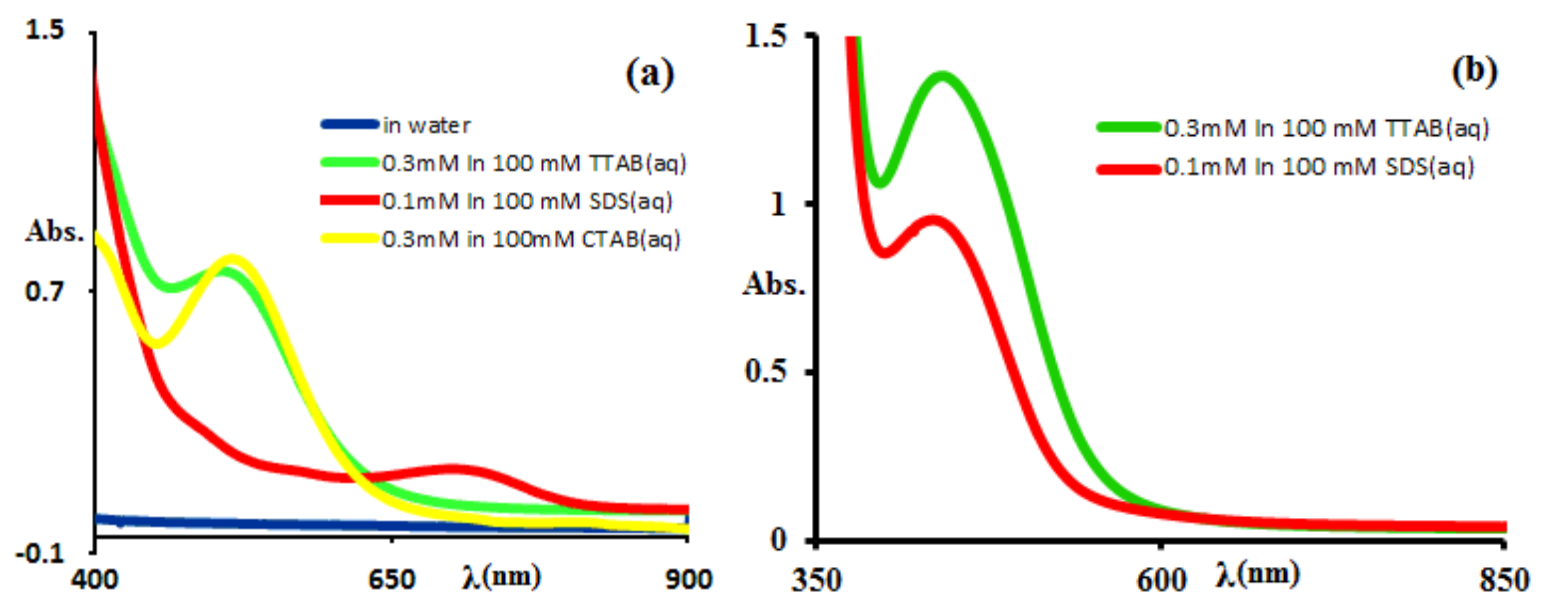

Figure 3: UV-Visible spectrum of nitrophenylferrocenes in different micelle membranes and water after 12 hour sonication a) for $\mathbf{A 1}$, b) for $\mathbf{A 5}$. (Spectra for compounds A2 - A4 is provided in supplementary materials) 


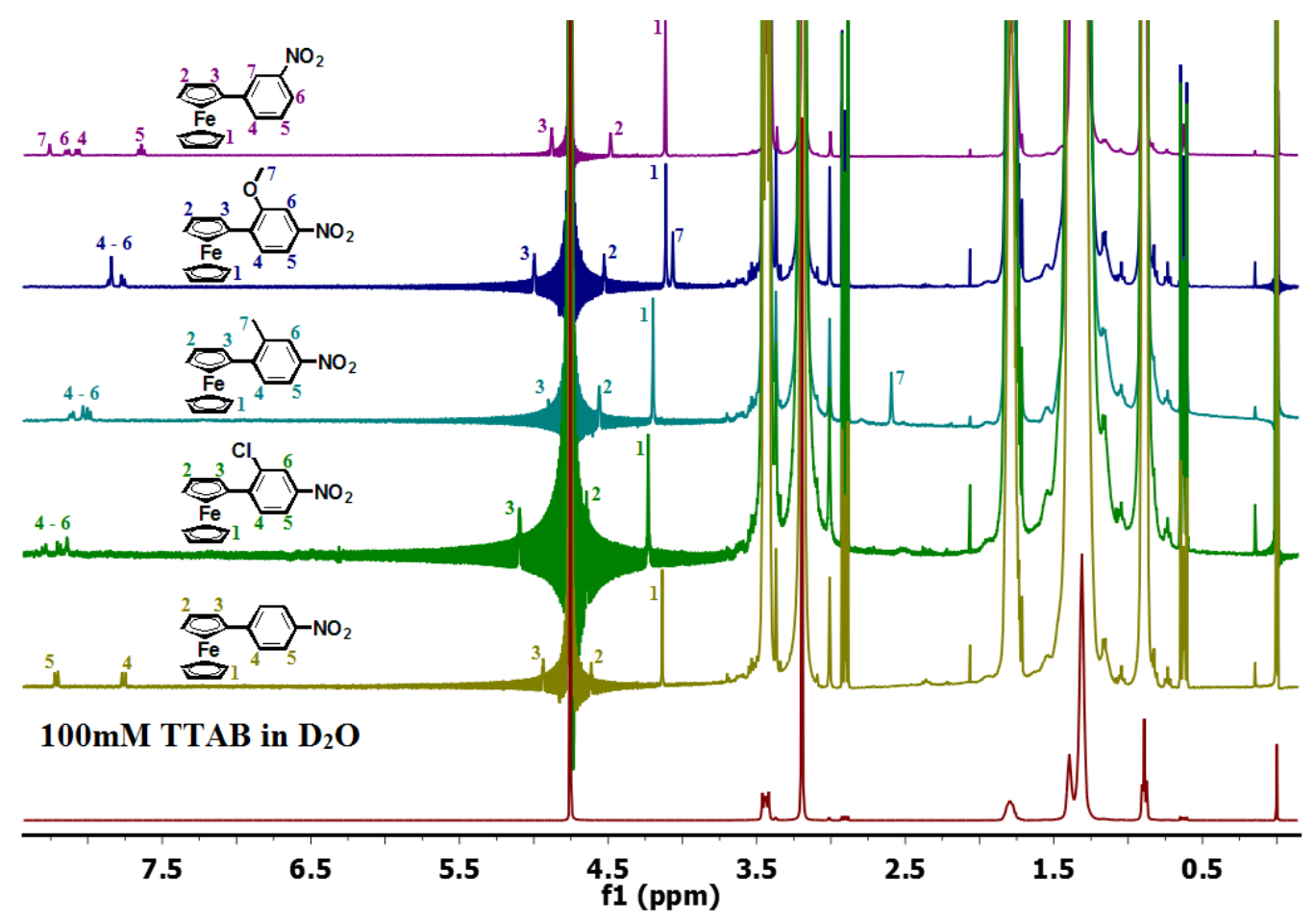

Figure 4: The ${ }^{1} \mathrm{HNMR}$ spectra of A1 - A5 in TTAB micelles made in $\mathrm{D}_{2} \mathrm{O}$, Probes and peaks are correlated by color and numbering scheme. The high intensity of micelle peaks is due to the high concentration. 


\section{Graphical Abstract}

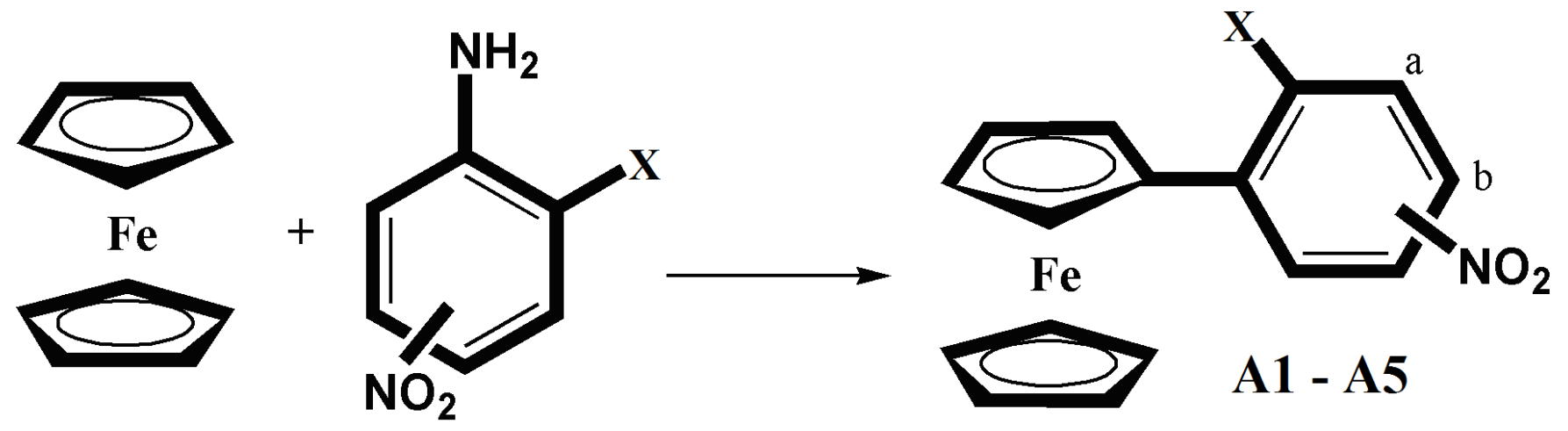

The selected compounds were tested against human ovarian cell lines; A2780, A2780cisR and A2780ZD0473R.
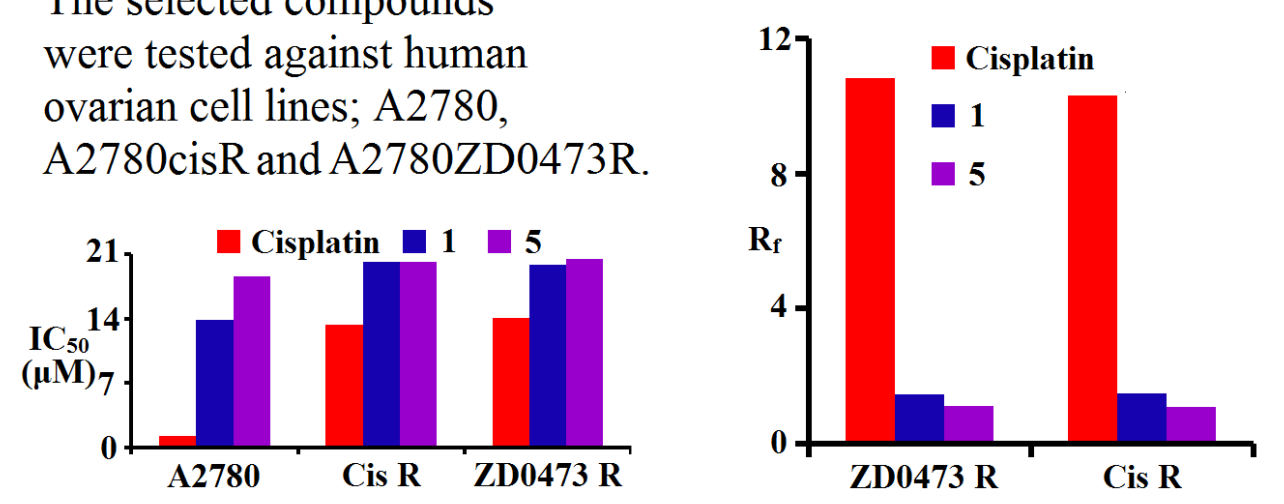

\begin{tabular}{l|l} 
Comp.| $\mathbf{X}, \mathbf{N O}_{2}$ Position \\
\hline $\mathbf{A 1}$ & $\mathbf{H}, \mathrm{b}$ \\
$\mathbf{A 2}$ & $\mathbf{C l}, \mathrm{b}$ \\
$\mathbf{A 3}$ & $\mathbf{C H}_{3}, \mathrm{~b}$ \\
A4 & $\mathbf{O C H}_{3}, \mathrm{~b}$ \\
A5 & $\mathbf{H}, \mathrm{a}$
\end{tabular}

Compounds for cell line studies were selected on the bases of results obtained in modal membrane uptake studies. All the compounds show penetration into $+\mathrm{Ve}$ and $-\mathrm{Ve}$ interface. $-\mathrm{Ve}$ interface cause oxidation of ferrocene to ferrocenium state in compounds A1 - A4, while compound A5 show resistance against oxidation.

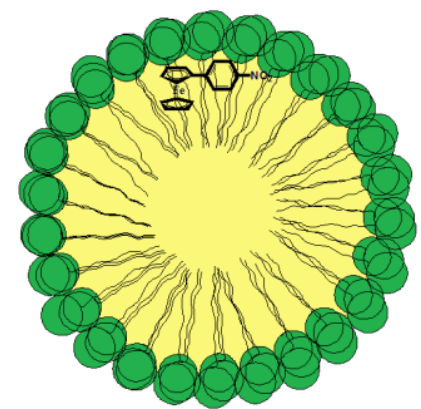

+ Ve interface of CTAB, TTAB

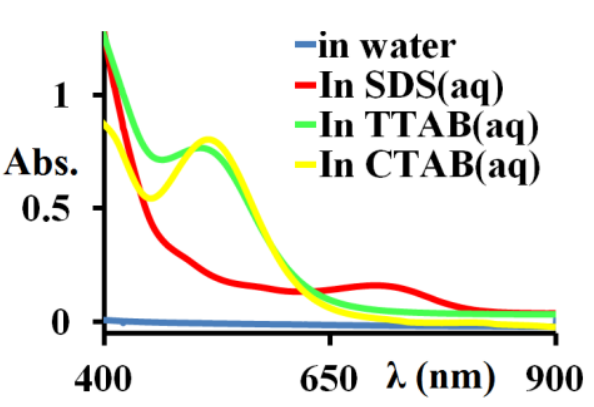

UV-Vis Spectral response of $\mathbf{1}$ in diffrent micell membranes

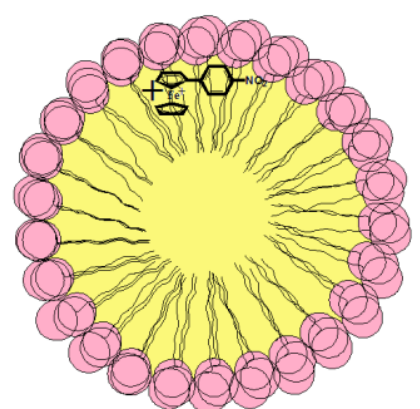
-Ve interface of SDS
cause oxidation 
Table 1: $\lambda_{\max }$ and apparent absorptivity $\left(\varepsilon_{\text {apr }}\right)$ of compounds $\mathbf{A 1}-\mathbf{A 5}$ in EtOH, TTAB $(a q)$ and $\operatorname{SDS}_{(\mathrm{aq})}$ micelles

\begin{tabular}{|c|c|c|c|c|c|c|c|c|c|c|}
\hline \multirow{2}{*}{ Solvent } & \multicolumn{2}{|c|}{ A1 } & \multicolumn{2}{|c|}{ A2 } & \multicolumn{2}{|c|}{ A3 } & \multicolumn{2}{|c|}{ A4 } & \multicolumn{2}{|c|}{ A5 } \\
\hline & $\lambda_{\max }$ & $\varepsilon_{\text {apr }}$ & $\lambda_{\max }$ & $\varepsilon_{\text {apr }}$ & $\lambda_{\max }$ & $\varepsilon_{\mathrm{apr}}$ & $\lambda_{\text {max }}$ & $\varepsilon_{\mathrm{apr}}$ & $\lambda_{\max }$ & $\varepsilon_{\mathrm{apr}}$ \\
\hline \multirow{4}{*}{ Ethanol } & 258 & 13675 & - & - & 278 & 13460 & - & - & 238 & 23000 \\
\hline & 327 & 18350 & 270 & 11260 & 315 & 15720 & 278 & 14181 & 269 & 18216 \\
\hline & 395 & 4500 & 338 & 16400 & 397 & 4080 & 356 & 17851 & 330 & 3516 \\
\hline & 503 & 3625 & 510 & 5020 & 490 & 3520 & 518 & 5030 & 430 & 506 \\
\hline \multirow{4}{*}{$\mathrm{CH}_{3} \mathrm{CN}$} & 250 & 20600 & & & & & & & & \\
\hline & 326 & 17725 & & & & & & & & \\
\hline & 397 & 4175 & & & & & & & & \\
\hline & 504 & 3675 & & & & & & & & \\
\hline \multirow{3}{*}{$n-C_{6} H_{14}$} & 321 & 36325 & & & & & & & & \\
\hline & 391 & 8600 & & & & & & & & \\
\hline & 481 & 6175 & & & & & & & & \\
\hline \multirow{3}{*}{$i-\operatorname{PrOH}$} & 317 & 21050 & & & & & & & & \\
\hline & 389 & 4925 & & & & & & & & \\
\hline & 497 & 3825 & & & & & & & & \\
\hline \multirow{3}{*}{ THF } & 325 & 35125 & & & & & & & & \\
\hline & 398 & 7475 & & & & & & & & \\
\hline & 501 & 6475 & & & & & & & & \\
\hline TTAB $_{(\mathrm{aq})}$ & 507 & - & 514 & - & 504 & - & 521 & - & 442 & - \\
\hline $\mathbf{S D S}_{(\mathrm{aq})}$ & 702 & - & 704 & - & 628 & - & 708 & - & 436 & - \\
\hline
\end{tabular}


Table 2: Selected bond lengths, angles and torsion angles for compound A2

\begin{tabular}{ll|ll|ll}
\hline \multicolumn{2}{l|}{ Bond lengths $(\AA)$} & \multicolumn{2}{l|}{ Bond angles $\left(^{\circ}\right)$} & & \multicolumn{2}{l}{ Torsion angles $\left(^{\circ}\right)$} & \\
\hline $\mathrm{Fe}-\mathrm{C} 6$ & 2.046 & $\mathrm{C} 4-\mathrm{Fe}-\mathrm{C} 6$ & 107.18 & $\mathrm{~N}-\mathrm{C} 14-\mathrm{C} 13-\mathrm{C} 12$ & -179.08 \\
$\mathrm{Fe}-\mathrm{C} 4$ & 2.048 & $\mathrm{Fe}-\mathrm{C} 6-\mathrm{C} 11$ & 128.35 & $\mathrm{~N}-\mathrm{C} 14-\mathrm{C} 15-\mathrm{C} 16$ & 179.32 \\
$\mathrm{C} 6-\mathrm{C} 11$ & 1.468 & $\mathrm{C} 12-\mathrm{C} 13-\mathrm{C} 14$ & 118.42 & $\mathrm{O} 1-\mathrm{N}-\mathrm{C} 14-\mathrm{C} 15$ & -176.54 \\
$\mathrm{C} 12-\mathrm{Cl}$ & 1.739 & $\mathrm{C} 11-\mathrm{C} 12-\mathrm{Cl}$ & 122.01 & $\mathrm{C}-\mathrm{C} 12-\mathrm{C} 11-\mathrm{C} 6$ & 1.480 \\
$\mathrm{C} 14-\mathrm{N}$ & 1.465 & $\mathrm{C} 13-\mathrm{C} 12-\mathrm{Cl}$ & 115.58 & $\mathrm{C} 12-\mathrm{C} 11-\mathrm{C} 6-\mathrm{C} 7$ & 26.55 \\
$\mathrm{C} 13-\mathrm{C} 14$ & 1.386 & $\mathrm{C} 13-\mathrm{C} 14-\mathrm{N}$ & 118.34 & $\mathrm{C} 12-\mathrm{C} 11-\mathrm{C} 6-\mathrm{C} 10$ & -156.61 \\
$\mathrm{~N}-\mathrm{O} 1$ & 1.220 & $\mathrm{~N}-\mathrm{C} 14-\mathrm{C} 15$ & 119.37 & $\mathrm{C} 10-\mathrm{C} 6-\mathrm{C} 11-\mathrm{C} 16$ & 23.53 \\
$\mathrm{~N}-\mathrm{O} 2$ & 1.235 & $\mathrm{O} 1-\mathrm{N}-\mathrm{O} 2$ & 123.65 & Fe1-C6-C11-C12 & -67.94 \\
$\mathrm{C} 1-\mathrm{C} 2$ & 1.427 & $\mathrm{C} 14-\mathrm{N}-\mathrm{O} 1$ & 118.33 & Fe1-C6-C11-C16 & 112.20 \\
\hline \multicolumn{7}{r}{}
\end{tabular}


Table 3: The intra-molecular and intermolecular H-bonding interactions in $\mathbf{A 2}$

\begin{tabular}{|c|c|c|c|c|c|c|}
\hline $\mathbf{X}$ & $\mathbf{H}$ & $\mathbf{Y}$ & $\begin{array}{c}\mathbf{d}(\mathbf{X}-\mathbf{H}) \\
(\AA)\end{array}$ & $\begin{array}{c}\text { d(H--Y) } \\
(\AA)\end{array}$ & $\begin{array}{c}d(X--Y) \\
(\stackrel{\AA}{A})\end{array}$ & $\begin{array}{c}<(\text { XHYY }) \\
\left({ }^{\circ}\right)\end{array}$ \\
\hline \multicolumn{7}{|c|}{ Intra-molecular hydrogen bonds } \\
\hline $\mathrm{C} 7$ & $\mathrm{H} 7$ & $\mathrm{Cl}$ & $0.980(2)$ & $2.656(1)$ & $3.156(3)$ & $111.99(6)$ \\
\hline $\mathrm{C} 16$ & H16 & $\mathrm{C} 10$ & $0.930(2)$ & $2.626(2)$ & $2.964(2)$ & $102.10(7)$ \\
\hline $\mathrm{C} 13$ & $\mathrm{H} 13$ & $\mathrm{O} 1$ & $0.930(2)$ & $2.418(3)$ & $2.706(2)$ & $97.85(8)$ \\
\hline $\mathrm{C} 15$ & $\mathrm{H} 15$ & $\mathrm{O} 2$ & $0.931(1)$ & $2.446(2)$ & $2.727(2)$ & $97.40(8)$ \\
\hline \multicolumn{7}{|c|}{ Intermolecular hydrogen bonds } \\
\hline $\mathrm{C} 16$ & H16 & $\mathrm{O} 2$ & 0.931 & 2.609 & 3.522 & 167.15 \\
\hline
\end{tabular}


Table 4: Literature comparative data for solvent dependent torsion angles and ferrocenylphenyl (C-C) bond distance

\begin{tabular}{|c|c|c|c|c|c|c|c|}
\hline \multirow[t]{2}{*}{ Comp. \# } & \multirow{2}{*}{$\begin{array}{l}\text { Compound } \\
\text { substituent }\end{array}$} & \multicolumn{2}{|c|}{$\begin{array}{l}\text { Torsion angle } \\
\left({ }^{\circ}\right)\end{array}$} & \multirow{2}{*}{\begin{tabular}{|l|} 
Ph-Cp \\
Bond \\
length \\
$(\AA)$ \\
\end{tabular}} & \multirow{2}{*}{$\begin{array}{l}\text { Fe to ortho } \\
\text { carbon } \\
\text { distance } \\
(\AA ̊ \AA)\end{array}$} & \multirow[t]{2}{*}{ Solvent } & \multirow[t]{2}{*}{\begin{tabular}{|l} 
Ref. \\
\end{tabular}} \\
\hline & & $\begin{array}{l}\text { Down } \\
\text { ward }\end{array}$ & $\begin{array}{l}\text { Up } \\
\text { ward }\end{array}$ & & & & \\
\hline A1 & $\mathrm{H}$ & 15.46 & 18.30 & 1.469 & 3.599 & $\begin{array}{l}\text { EtOAc/D } \\
\mathrm{CM}\end{array}$ & [31] \\
\hline A1 & $\mathrm{H}$ & 11.27 & 13.32 & 1.466 & 3.704 & $\begin{array}{l}\mathrm{EtOH} / \mathrm{DC} \\
\mathrm{M}\end{array}$ & [32] \\
\hline A1 & $\mathrm{H}$ & & 12.5 & 1.455 & & $\mathrm{MeOH}$ & [35] \\
\hline A2 & $\mathrm{Cl}$ & 26.55 & 23.53 & 1.468 & 3.890 & Iso octane & This work \\
\hline A4 & $\mathrm{OCH}_{3}$ & 23.33 & 22.18 & 1.466 & 3.670 & Iso octane & This work \\
\hline A5 & $\mathrm{H}$ & & 17.4 & 1.463 & & $\mathrm{MeOH}$ & [35] \\
\hline A5 & $\mathrm{H}$ & 4.95 & 8.55 & 1.497 & 3.864 & n-Hexane & [36] \\
\hline $\begin{array}{l}\text { p-Fc } \\
\text { aniline }\end{array}$ & $\mathrm{H}$ & 7.60 & 8.29 & 1.477 & 3.965 & $\begin{array}{l}\text { Hexane } \\
\text { /EtOAc }\end{array}$ & [37] \\
\hline $\begin{array}{l}\text { Non } \\
\text { conjugated } \\
\text { system }\end{array}$ & - & - & - & 1.493 & & $\begin{array}{l}\mathrm{CH}_{2} \mathrm{Cl}_{2} / \\
\mathrm{MeOH}\end{array}$ & [38] \\
\hline$F c-F c$ & - & 49.9 & 55.7 & 1.477 & & EtOAc & [39] \\
\hline
\end{tabular}


Table 5: ${ }^{1} \mathrm{HNMR}$ data of A1 - A5 in different solvents, CTAB and TTAB micelles*

\begin{tabular}{|c|c|c|c|c|c|c|}
\hline \multirow[b]{2}{*}{ Molecule } & \multicolumn{3}{|c|}{ Ferroocene region } & \multirow[b]{2}{*}{ Aromatic region } & \multirow[b]{2}{*}{ R group } & \multirow{2}{*}{$\begin{array}{l}\text { No. of probe } \\
\text { Molecules } \\
\text { per micelle }\end{array}$} \\
\hline & $\begin{array}{c}\text { Cp ring } \\
(\mathrm{s}, 5 \mathrm{H})\end{array}$ & $\begin{array}{c}\text { Cp ring } \\
(\mathrm{t}, 2 \mathrm{H})\end{array}$ & $\begin{array}{c}\text { Cp ring } \\
(\mathrm{t}, 2 \mathrm{H})\end{array}$ & & & \\
\hline $\mathbf{A 1}$ in $\mathrm{CDCl}_{3}$ & 4.047 & 4.465 & 4.734 & $7.549,8.132$ & & - \\
\hline A1 in Acetone- $\mathrm{d}^{6}$ & 4.084 & 4.524 & 4.961 & $7.798,8.153$ & & - \\
\hline A1 in iso-octane ${ }^{* * * *}$ & 4.034 & 4.417 & 4.699 & $7.530,8.145$ & & - \\
\hline A1 in cyclohexane- $\mathrm{d}^{12}$ & 3.947 & 4.333 & 4.616 & $7.459,8.060$ & & 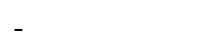 \\
\hline A1 in CTAB & 4.128 & ---- & 4.928 & $7.751,8.201$ & & 1.04 \\
\hline $\mathbf{A 1}$ in $75 \mathrm{mM} \mathrm{CTAB}$ & 4.127 & ---- & 4.926 & $7.748,8.201$ & & \\
\hline $\mathbf{A 1}$ in TTAB & 4.135 & 4.614 & 4.937 & $7.759,8.210$ & & 0.94 \\
\hline $\mathbf{A 2}$ in $\mathrm{CDCl}_{3}$ & 4.273 & 4.585 & 4.994 & $7.730,8.012,8.208$ & $\mathrm{Cl}$ & - \\
\hline $\mathbf{A 2}$ in $\mathrm{TTAB}$ & 4.229 & 4.643 & 5.096 & $8.140,8.195,8.295$ & $\mathrm{Cl}$ & 1.39 \\
\hline $\mathbf{A 3}$ in $\mathrm{CDCl}_{3}$ & 4.230 & 4.506 & 4.693 & $7.618,7.954-7.999$ & $\mathrm{CH}_{3}(2.525)$ & - \\
\hline A3 in TTAB & 4.197 & 4.559 & 4.903 & $7.993,8.033,8.108$ & $\mathrm{CH}_{3}(2.592)$ & 1.55 \\
\hline $\mathbf{A 4}$ in $\mathrm{CDCl}_{3}$ & 4.058 & 4.425 & 4.869 & $7.607,7.741-7.814$ & $\mathrm{OCH}_{3}(4.013)$ & \\
\hline A4 in TTAB & 4.111 & 4.526 & 4.996 & $7.764,7.842,7.863$ & $\mathrm{OCH}_{3}(4.065)$ & 1.21 \\
\hline $\mathrm{A} 5 \mathrm{in} \mathrm{CDCl}_{3}$ & 4.069 & 4.419 & 4.727 & $7.440,7.763,8.026,8.279$ & - & - \\
\hline A5 in TTAB & 4.113 & 4.482 & 4.878 & $7.640,8.069,8.139,8.258$ & - & 2.86 \\
\hline
\end{tabular}

*All the micelle solutions for NMR study were made in $\mathrm{D}_{2} \mathrm{O}$ with $100 \mathrm{mM}$ surfactant concentration other wise mentioned.

*** Number of probe molecules per micelle calculated by considering aggregation number for TTAB $=100^{[42]}$

**** NMR spectra of iso-octane solution were taken by locking and shimming on cyclohexane- $\mathrm{d}^{12}$ 
Table 6: $\mathrm{IC}_{50}$ value and resistance factor $\left(\mathrm{R}_{\mathrm{f}}\right)$ for cisplatin, $\mathbf{A 1}$ and $\mathbf{A 5}$

\begin{tabular}{l|l|l|l|l|l}
\hline Compounds & $\begin{array}{l}\mathrm{A} 2780 \\
\mathbf{I C}_{\mathbf{5 0}}(\mu \mathrm{M})\end{array}$ & $\begin{array}{l}\mathrm{A} 2780^{\mathrm{cisR}} \\
\mathbf{I C}_{\mathbf{5 0}}(\mu \mathrm{M})\end{array}$ & $\begin{array}{l}\mathrm{IC}_{50} \mathrm{~A} 2780^{\mathrm{ciSR}} \\
/ \mathrm{IC}_{50} \mathrm{~A} 2780 \\
\mathbf{R}_{\mathbf{f}}\end{array}$ & $\begin{array}{l}\mathrm{A} 2780^{\mathrm{ZD} 0473 \mathrm{R}} \\
\mathbf{I C}_{\mathbf{5 0}}(\mu \mathrm{M})\end{array}$ & $\begin{array}{l}\mathrm{IC}_{50} \mathrm{~A} 2780^{\mathrm{ZD} 0473 \mathrm{R}} \\
/ \mathrm{IC}_{50} \mathrm{~A} 2780 \\
\mathbf{R}_{\mathbf{f}}\end{array}$ \\
\hline Cisplatin & 1.30 & 13.39 & 10.30 & 14.08 & 10.83 \\
A1 & 13.84 & 20.18 & 1.46 & 19.87 & 1.44 \\
A5 & 18.59 & 20.12 & 1.08 & 20.50 & 1.10 \\
\hline
\end{tabular}

